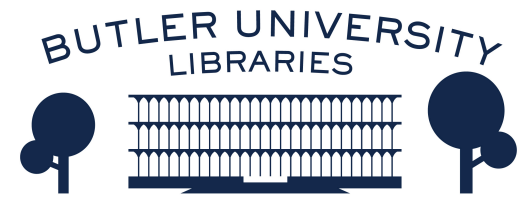

Journal of Hindu-Christian Studies

Volume 25

Article 13

November 2012

\title{
Book Review: "Dalit Theology and Dalit Liberation: Problems, Paradigms and Possibilities" by Peniel Rajkumar
}

Sathianathan Clarke

Follow this and additional works at: https://digitalcommons.butler.edu/jhcs

Part of the Religion Commons

\section{Recommended Citation}

Clarke, Sathianathan (2012) "Book Review: "Dalit Theology and Dalit Liberation: Problems, Paradigms and Possibilities" by Peniel Rajkumar," Journal of Hindu-Christian Studies: Vol. 25, Article 13.

Available at: https://doi.org/10.7825/2164-6279.1519

The Journal of Hindu-Christian Studies is a publication of the Society for Hindu-Christian Studies. The digital version is made available by Digital Commons @ Butler University. For questions about the Journal or the Society, please contact cbauman@butler.edu. For more information about Digital Commons @ Butler University, please contact digitalscholarship@butler.edu. 


\section{BOOK REVIEWS}

\section{Dalit Theology and Dalit Liberation: Problems, Paradigms and Possibilities. Peniel Rajkumar. Farnham, UK: Ashgate, 2010,}

\section{$224+$ xi pages.}

DALIT theology is a context-specific expression of people's God-talk that has real consequences for the lives of marginalized communities in India. Founded in the good news that a new world order has been announced and initiated by Jesus Christ, 'broken' men and women, who were 'crushed' and 'rent asunder' by the caste system (These three terms are most commonly used as English translations for the word 'Dalit'), continuously seek liberation from their inhumane condition of bondage and entry into the promised reign of God where dignity, freedom and justice prevail on earth as it is in heaven. Peniel Rajkumar joins this three-decade long theological reflection with honesty, modesty and originality. In this expansively researched and artfully argued book Rajkumar sets out to critically interrogate, constructively reappropriate and creatively re-imagine Dalit theology for the liberation of Dalits as well as non-Dalits in India. This results in a valuable theological contribution both to Indian contextual theologies and global liberation theologies as they seek to live promisingly and productively in the twenty-first century.

Through an extended Introduction, seven cogently designed and tightly assembled chapters, and a brief Conclusion, Rajkumar works out his project to creatively infuse motifs of liberation into dalit theology in order to bolster its "practical efficacy" and enhance its "praxis of partnership" to include non-dalits. The Introduction is intended to provide the needed backdrop for understanding just who the Dalits are within the caste-based Indian society. After a somewhat hurried summary of "the Aryan theory," which is rooted in racial ancestry, to comprehend the origin and spread of the caste system in India (pp. 6 \& 7) Rajkumar stacks the deck in favor of endorsing the "purity and pollution theory." (pp. 7-19). One needs to wait for his constructive contribution to detect the similarities between the Indian ritually-based social division and the fractured socio-religious context of first century Palestine. The healing dimensions of Jesus' work in the bible stories thus readily and fittingly become relevant in addressing the present day caste-divide in the Indian situation.

Chapter one sets about answering some basic although large questions: the why, what and how of Dalit theology? After a swift yet credible sweep of Indian theology across at least five centuries Rajkumar suggests that the "paradigm shift that Dalit theology envisaged for the Indian Christian theological task was to decisively make dalit issues the new focus of theologizing in India." (p. 40) He argues through the rest of this chapter that the transformative thrust of such dalit theologizing can be captured in "a dialectics between identity affirmation and liberative social vision." (p. 41) The issue of Identity affirmation, according to Rajkumar, is explored comprehensively and creatively by dalit theology, which may explain the assertion of dalit subjectivity in Christian circles. However, the liberative social vision of Dalit theology is shown to be constricted (securing "Schedule Caste benefits to Christian Dalits" p. 54) and insular ("overcoming caste discrimination within the Churches" p. 54).

Chapters two and three are formulated to complement each other. Chapter two puts forward some dominant ways by which theology diverts Dalits from their responsibility of conceptualizing and actualizing a liberative social vision. Two examples will suffice. First, Dalit theology constantly entreats the Church to stand in solidarity with the plight of the Dalits. Clearly, this misses the truth that the 
church itself is a community of Dalits that needs to own and live out the ethical praxis of liberation in the real world. Second, Dalit theology tends to remain trapped in text books circulated in closed settings, such as seminaries, as though it has little relevance for Christian communities that aspire to live in freedom with justice within a caste-ridden world. Chapter three suggests that the way forward for Dalit theology lies in using narratives of the Bible to engender a practical liberative vision, which alone will have currency in the life of local Christian communities. At this crucial juncture of the book Rajkumar makes a fundamental but arbitrary decision about the central biblical narrative that will frame and fuel his praxisoriented and people-centered theology: Jesus' healing stories from the synoptic Gospels becomes his biblical canon for re-constructing dalit theology. While a host of western and some Indian scholars are consulted in establishing a sound case for the paradigmatic role of such healing stories of Jesus for Christian reflection in general, nothing is presented by Rajkumar to indicate that such healing stories play any role in the native theologies and/or spiritual practices of local Dalit communities.

Chapter four is an original and resourceful contribution to Dalit theology and ethics. Rajkumar uses the healing stories of Jesus to construct a Christian ethical framework that can both spur and feed Dalit resistance against caste discrimination and carve and cultivate space for just living that includes all communities. Four themes emerge from Jesus' healing stories that serve as templates for such a broad ethical framework: touch as subverting uncleanness codes of purity and pollution; faith as initiative toward wholeness rather than passive acceptance of status quo; conflict and confrontation as pedagogical objects in healing narrations; and compassion as binding both healed and healer into an inclusive community of wholeness.

Chapters five, six and seven weave the textual warp of three specific healing stories of Jesus with the contextual woof of the world of Dalits to re-inscribe and re-imagine Dalit theology. Theological orientation for liberative praxis is conscientiously and creatively crafted by meshing biblical Word-visions with Dalit world-versions. In chapter five Christology is revisited by a re-reading of Jesus' healing of the leper (Mark 1: 40-45). Two ideas emerge: first, boundaries are transcended by both Jesus and the leper through a liberating process of trespassing divisive social conventions; and second, the Jesus that emerges as empowering for Dalit theology is the liberating Christ rather than the suffering servant. Chapter six contains a rich and imaginative interpretation of Jesus' exorcism of a man possessed with a demon (Mark 5: 1-20). Dalit theology can extract valuable lessons on agency from this encounter. Rajkumar challenges Dalit theology's contentment with only lifting high the resistive quality of its symbol system without embracing opportunities to be engaged in actual resistance in the real world. The seventh chapter uses the healing story of Jesus involving the Syrophoenician in Matthew (15: 21-28) and Mark (7: 24-30). In this chapter Rajkumar offers an alternative to the unhelpfully protracted navel gazing propensity of Dalit theology. The preoccupation with its own identity assertion and affirmation as violated other is profitably redirected toward embracing an "other-centered praxis" of "mutual engagement" and "openness." Dalit theology is thus enabled to circumvent its parochial agenda and undertake the more comprehensive mission of "evolving integrationist and inclusive models of praxis for Dalit theology" (p. 179) that would encompass the non-Dalit other as well. The Conclusion is a succinct summary of the argument of the book that helps the reader recapitulate the author's central theological prepositions.

I have read Peniel Rajkumar's Dalit Theology and Dalit Liberation: Problems, Paradigms and Possibilities with great interest and enthusiasm. Let me without any hesitation say that this is the most thorough, original and thoughtprovoking book on Indian theology that I have read over the last ten years. It does a splendid job of both intelligibly interpreting and convincingly criticizing Dalit theology over the last 30 years. Yet it does not stop with such legitimate pronouncements. Peniel Rufus also 
takes on the challenge of creatively reconstructing directions for Dalit theology that are practical, biblical, inclusionary and liberative. These creative moves represent the most substantial and enriching section of the book. Moreover, in this contribution the vistas of theology are opened up to address concerns that include Dalits and non-Dalits. A more universal role is carved out for Dalit visions. All human beings and their eventual liberation matter to Dalit communities. In this sense Dalit theology is not merely an assertion of one human particularity but an aspiration for the liberation of all human beings.

There are a couple of critical comments I wish to register. First, Rajkumar's interpretation of the caste system replicates the same weakness that he identifies with Dalit theology: robust in churning out convincing theory but ineffectual when accounting for actual practice. His interpretation maps out the stringent divisions and blatant discriminations that underpin the rationale of caste system. This is no doubt an effective way of maintaining great distance between the Dalit's world of pollution and the Caste community's world of purity. Yet Rajkumar turns a blind eye towards the incalculable and boundless practices of Dalit subversions, Caste-Dalit negotiations, and Caste resignations that live and proliferate in the space in-between such theoretical formulations of purity and pollution. An uncritical inflation of fixity and negligent disregard of fluidity in the functioning of purity and pollution reinforces a stereotype of the power of caste communities in contrast to the powerlessness of the Dalit. Thus, even if useful for valorizing a bridging role for Jesus in the theoretical caste-Dalit divide, one is left with the unhelpful erasure of overt and covert manifestations of the calculating practices of Dalit agency. No wonder then that Rajkumar is stuck with the language of "victims" in referencing Dalits: "The Dalits are the victims of a social system, which sought (and still seeks) to maintain a feigned notion of auspiciousness, purity and pollution." (p. 19).

Second, I am not convinced that "practical efficacy" of Dalit theology ought to be the single criterion by which one evaluates the discipline. Surely meaningfulness and metaphysical plausibility can be added to the effectiveness of theology. But even if one lets Rajkumar have his praxiological cake alone one must ask the question as to whether the people eating the cake have had much to say on the matter of whether it is satisfactory as their meal? Perhaps what has emerged as Dalit theology in academe-produced texts does not get transferred to aid Dalit Christian practice on the ground. However, I am not so sure that another imaginative, even if praxis-committed, text that is founded in Jesus' healing stories has a better chance of success. All this talk of bridging the gap between thought and practice seems to presuppose that individual Christian Dalits and grass root Christian communities are not living their theological aspirations. I am convinced that local communities have microscripts of liberative praxis that are operative, even of partially and tentatively. One may need to see liberation praxis as a collection of microactions, micro-rituals and micro-beliefs that work tacitly and cryptically. Liberative narratives may emerge when such sources are correlated with biblical speech-acts of Jesus including healing stories. Sourcing of Dalit theology must take place on the ground rather than for the ground. Our vocation as Dalit theologians thus may lie in construing theoretical validity for what is pragmatically already extant even of not fully effectual. After all, magnificent bridges of stone and steel that are constructed without the earthy canals of mud and straw may be conceptually stable but concretely irrelevant.

Sathianathan Clarke

Wesley Theological Seminary, Washington D. C.

\section{A Christian Pilgrim in India: The Spiritual Journey of Swami Abhishiktananda (Henri Le Saux). Harry Oldmeadow. Bloomington, IN: World Wisdom, 2008, xvi + 316 pp.}

